\title{
Impact of surgery on quality of life in Crohn's disease patients: final results of Czech cohort
}

\author{
Lumir Kunovsky ${ }^{1,2}$, Ladislav Mitas ${ }^{1}$, Filip Marek1', Jiri Dolina², Karolina Poredska², Lenka Kucerova², \\ Klara Benesova ${ }^{3,4}$, Zdenek Kala' \\ 'Department of Surgery, University Hospital Brno, Medicine of adult age (Bohunice), and Faculty of Medicine, \\ Masaryk University, Brno, Czech Republic \\ 2Department of Gastroenterology, University Hospital Brno, Medicine of adult age (Bohunice), and Faculty of Medicine, \\ Masaryk University, Brno, Czech Republic \\ 3 Institute of Biostatistics and Analyses, Faculty of Medicine, Masaryk University, Brno, Czech Republic \\ ${ }^{4}$ Institute of Health Information and Statistics of the Czech Republic, Prague, Czech Republic
}

\begin{abstract}
Summary
Introduction: Crohn's disease (CD) belongs to chronic diseases that highly affect the patient's quality of life (QoL). The effect of the disease and impairment of QoL in CD patients is already known. The aim was to assess how surgical treatment influences the patients' QoL and determine factors that can affect postoperative QoL. Methods and patients: We compared the QoL before and after surgery in patients who had undergone a bowel resection at our department due to CD between 2010-2016. The patients filled in a standardized QLQ-CR29 questionnaire to assess QoL in the preoperative period and the postoperative period after a 2-month interval. The control groups were $\mathrm{CD}$ patients who had not undergone surgical treatment (bowel resection) and a healthy cohort. In the QoL evaluation, 132 patients with $C D$ who had undergone surgery (bowel resection), 83 patients with $C D$ without an operation and 104 healthy subjects were enrolled. Results: 104 of the operated patients experienced a postoperative improvement of the overall QoL (78.8 \%), 2 patients did not register any changes in QoL (1.5 \%) and 26 patients (19.7 \%) experienced a worsening of their postoperative QoL. The results were statistically significant $(p<0.001)$. Conclusion: We detected a significant improvement of the overall QoL after surgical resection in CD patients (measured 2 months after surgery). Gender was identified as the only statistically relevant factor with influence on postoperative QoL.
\end{abstract}

Key words: bowel resection - Crohn's disease - Czech cohort - inflammatory bowel disease - quality of life - surgical treatment

\section{Vliv chirurgické léčby na kvalitu života u pacientů s Crohnovou chorobou: finální výsledky české kohorty}

\section{Souhrn}

Úvod: Crohnova nemoc (Crohn's disease - CD) patří mezi chronické onemocnění, které značně ovlivňuje kvalitu života (quality of life - QoL) u těchto pacientů. Cílem studie bylo stanovit, jaký vliv má chirurgická léčba na kvalitu života (quality of life - QoL) u pacientů S CD a určit faktory, které ovlivňují pooperační QoL. Metody a pacienti: Porovnávána byla QoL před operací a v pooperačním období u pacientů, kteří podstoupili na Chirurgické klinice střevní resekci z indikace CD v letech 2010-2016. Pacienti vyplnili standardizovaný dotazník k měření QoL QLQCR29 v předoperačním období a po operaci s odstupem 2 měsíců. Kontrolní skupiny představovali pacienti s CD, kteří nepodstoupili chirurgickou léčbu (resekci střeva) a zcela zdravá kohorta osob. Do studie bylo celkem zahrnuto 132 operovaných pacientů pro $C D$ (resekce střeva), 83 pacientů $\mathrm{C} C$ bez operace a 104 zdravých jedinců. Výsledky: Pooperační zlepšení QoL bylo zjištěno celkem u 104 operovaných pacientů $(78,8 \%)$, u 2 pacientů nebyla zaznamenána žádná změna v QoL $(1,5 \%)$ a u 26 pacientů $(19,7 \%)$ bylo zjištěno zhoršení pooperační QoL. Výsledky byly statisticky signifikantně významné $(p<0,001)$. Závěr: Prokázali jsme signifikantní zlepšení celkové QoL po střevní resekci u pacientů S CD v měřeném intervalu 2 měsíce od operace. Pohlaví bylo vyhodnoceno jako jediný statisticky významný faktor ovlivňující pooperační QoL

Klíčová slova: Crohnova choroba - česká kohorta - chirurgická léčba - idiopatické střevní záněty - kvalita života resekce střeva 


\section{Introduction}

Crohn's disease (CD) is a chronic, relapsing inflammatory disease of gastrointestinal tract which highly affects the quality of life (QoL). Health-related QoL is impaired in inflammatory bowel disease (IBD) patients, mostly due to chronicity, unpredictable disease course, young age onset, etc [1-4]. IBD patients may suffer from stressors such as abdominal discomfort, rectal bleeding, diarrhea, fecal urgency, weight loss, extraintestinal manifestations and a need for long-term medical therapy [2]. Therefore there has been a poorer QoL in IBD patients assessed compared with a healthy population $[1,2,5-9]$.

Previous studies showed that the disease activity and remission of the disease have the strongest impact on QoL in IBD patients [10-12]. Even with modern biological therapy possibilities, most CD patients have to undergo surgery during their lives (about $80 \%$ of CD patients) [13-18]. The main aim of this study was to find out the impact of surgical therapy in CD patients. We follow up on our previous article published in 2016 with the first results of QoL and bring the final data [19].

\section{Methods}

Our main studied group were patients who underwent bowel resection for CD. Patients who were operated for perianal disease (abscess, fistula) were not included in the study. We studied patients who underwent surgery for $C D$ at the Department of Surgery University hospital in Brno Bohunice between 2010-2016. The patients filled in a standardized QoL QLQ-CR29 questionnaire (Quality of life questionnaire-colorectal 29) prior to the surgery as well as after the surgery $[20,21]$. The questionnaire was filled in by patients indicated for bowel resection six weeks prior to their surgery and two months after the surgery. The two-month interval was selected as a sufficiently long period for convalescence, while short enough to avoid a relapse of the disease in anastomosis.

The first control group consisted of CD patients who did not undergo surgery for this diagnosis and had been diagnosed with $C D$ for at least 5 years. This group represented patients with a less aggressive form of the disease who did not require surgery. We supposed a better QoL in these patients compared to the main group.

The second control group was a healthy cohort. The individuals included in this group were healthy subjects without any disease or internal diagnosis who had not undergone any abdominal surgery. We naturally supposed the best QoL in this group. Both control groups filled in the QoL questionnaire only once. The study was approved by the Ethical committee of the University hospital Brno and all patients signed an informed consent.

Apart from our main aim, which was to find out how surgical treatment influences patients with $C D$, we tried to determine the factors affecting postoperative QoL in CD patients. The basic parameters included age, gender, basic data according to the Montreal classification, duration of the disease, medication, comor- bidity and smoking. Furthermore, we also monitored peroperative and postoperative data (type of surgery, operative approach and postoperative complications).

\section{Questionnaire and statistics}

The standardized QoL QLQ-CR29 questionnaire is divided into several parts $[20,21]$. It included questions focused on abdominal pain and discomfort, questions concerning sexual and urinary functions, questions regarding physical functioning and body image and questions related to stool and quality of defecation. The section focused on stool included questions concerning the frequency of defecation and the frequency of blood or mucus in stool. The quality of defecation was assessed based on the type of flatulence, fecal incontinence and perianal discomfort.

A total of $215 \mathrm{CD}$ patients and 104 healthy controls were included in the analysis. $132 \mathrm{CD}$ patients underwent operation for $C D, 83 C D$ patients did not have a CD-related operation. Standard descriptive statistics were applied in the analysis: absolute and relative frequencies for categorical variables and median with interquartile range (IQR) for continuous variables. The level and variation of QoL components was presented as mean and standard deviation, the Wilcoxon signedrank test was performed to assess the difference between preoperative and postoperative components of the QoL. The Mann-Whitney U test or Kruskal-Wallis oneway ANOVA for $\mathrm{k}$ samples was used to assess the association between the overall QoL and selected clinical characteristics as well as to compare the QoL between CD patients and healthy controls. To treat the effect of multiple comparisons, the Bonferroni correction was applied. If not specified otherwise, the $p<0.05$ was considered statistically significant for all analyses. Statistical analyses were performed in SPSS Statistics for Windows, version 24.0 (IBM Corp., Armonk, NY, USA).

\section{Patients}

The group which underwent bowel resection for $C D$ consisted of 132 patients out of which 59 were men $(44.7 \%)$ and 73 women ( $55.3 \%)$. The median age of patients at the time of surgery was 33 years of age (IQR 25-39 years). The prevailing location of the disease was the ileum (L1) in 71 of the cases (53.8\%) and a simultaneous disease involvement of the ileum and colon (L3) in 52 of the cases (39.4\%). The structuring form of the disease (B2) was the most common, in $55.3 \%$ of the patients. The perianal disease was present in 35 patients (26.5\%). As for preoperative medication, only $7.6 \%$ of patients had biological treatment, $12.9 \%$ were not using any pharmacotherapy, $27.3 \%$ of the patients had monotherapy and $52.3 \%$ were on a combination of 2-3 types of medication (Table 1).

The group of $C D$ patients who did not require surgical treatment consisted of 83 patients, 28 men (33.7\%) and 55 women (66.3\%). The median duration of CD was 13 years (9-17 years IQR). In the non-operated group, 
the prevailing location of the disease was, as in the main group, the ileum (L1), unlike the form of the disease, where the inflammatory type (B1) was the most common one; $16.9 \%$ of the patients had biological treatment, while most of the patients, $43.4 \%$ in particular, only used monotherapy in their CD treatment.

The healthy cohort, i. e. subjects without any disease, consisted of 104 subjects out of which $40.4 \%$ were men

\begin{tabular}{|c|c|c|c|c|c|}
\hline parameters & & $\begin{array}{l}\text { operated CD patients } \\
\qquad N=132\end{array}$ & $\begin{array}{c}\begin{array}{c}\text { non-operated } C D \\
\text { patients } \\
N=83\end{array} \\
\text { N }\end{array}$ & $\begin{array}{l}\text { controls } \\
\mathrm{N}=104\end{array}$ & $\mathbf{P}^{1}$ \\
\hline \multirow{2}{*}{ sex } & male & $59(44.7 \%)$ & $28(33.7 \%)$ & $42(40.4 \%)$ & \multirow{2}{*}{0.276} \\
\hline & female & $73(55.3 \%)$ & $55(66.3 \%)$ & $62(59.6 \%)$ & \\
\hline \multirow{4}{*}{ age at diagnosis } & years (median) & $26(20 ; 33)$ & $24(20 ; 30)$ & - & 0.177 \\
\hline & $<17$ years & $15(11.4 \%)$ & $4(4.8 \%)$ & - & \multirow{3}{*}{0.065} \\
\hline & $17-40$ years & $103(78.0 \%)$ & 75 (90.4 \%) & - & \\
\hline & $>40$ years & $14(10.6 \%)$ & $4(4.8 \%)$ & - & \\
\hline \multirow{4}{*}{ age at surgery } & years (median) & $33(25 ; 39)$ & - & - & - \\
\hline & $<17$ years & $0(0.0 \%)$ & - & - & \\
\hline & $17-40$ years & $103(78.0 \%)$ & - & - & \\
\hline & $>40$ years & $29(22.0 \%)$ & - & - & \\
\hline \multirow{3}{*}{ cigarette smoking } & smoker & $45(34.1 \%)$ & $25(30.1 \%)$ & $22(21.2 \%)$ & \multirow{3}{*}{0.002} \\
\hline & ex-smoker & $31(23.5 \%)$ & $16(19.3 \%)$ & $11(10.6 \%)$ & \\
\hline & non-smoker & $56(42.4 \%)$ & $42(50.6 \%)$ & $71(68.3 \%)$ & \\
\hline \multirow{4}{*}{ location of disease } & L1 - ileum & 71 (53.8\%) & $40(48.2 \%)$ & - & \multirow{3}{*}{0.125} \\
\hline & L2 - colon & $9(6.8 \%)$ & $13(15.7 \%)$ & - & \\
\hline & L3 - ileum + colon & $52(39.4 \%)$ & $30(36.1 \%)$ & - & \\
\hline & $\begin{array}{l}\text { L4 - upper } \\
\text { gastrointestinal tract } \\
\text { (concomitant) }\end{array}$ & $6(4.5 \%)$ & $7(8.4 \%)$ & - & 0.255 \\
\hline \multirow{3}{*}{ behaviour of disease } & B1 - inflammatory & $19(14.4 \%)$ & $74(89.2 \%)$ & - & \multirow{3}{*}{$<0.001$} \\
\hline & B2 - stricturing & $73(55.3 \%)$ & $5(6.0 \%)$ & - & \\
\hline & B3 - penetrating & $40(30.3 \%)$ & $4(4.8 \%)$ & - & \\
\hline perianal disease & & $35(26.5 \%)$ & $8(9.6 \%)$ & - & 0.003 \\
\hline \multirow{7}{*}{$\begin{array}{l}\text { preoperative } \\
\text { medication }\end{array}$} & no medication & $17(12.9 \%)$ & $3(3.6 \%)$ & - & \multirow{4}{*}{0.001} \\
\hline & biological treatment & $10(7.6 \%)$ & $14(16.9 \%)$ & - & \\
\hline & 1 type of medication ${ }^{2}$ & $36(27.3 \%)$ & $36(43.4 \%)$ & - & \\
\hline & $2-3$ types of medication ${ }^{2}$ & $69(52.3 \%)$ & $30(36.1 \%)$ & - & \\
\hline & 5-aminosalycites ${ }^{3}$ & $86(65.2 \%)$ & $55(66.3 \%)$ & - & 0.884 \\
\hline & immune suppressors ${ }^{3}$ & $47(35.6 \%)$ & $33(39.8 \%)$ & - & 0.564 \\
\hline & steroids ${ }^{3}$ & $58(43.9 \%)$ & $19(22.9 \%)$ & - & 0.002 \\
\hline \multicolumn{2}{|c|}{ duration of disease (years) } & $9(5 ; 14)$ & $13(9 ; 17)$ & - & $<0.001$ \\
\hline \multicolumn{2}{|c|}{ time from diagnosis to surgery (years) } & $5(2 ; 11)$ & - & - & - \\
\hline
\end{tabular}

${ }^{1}$ P-value of Fisher's exact test for categorical variables or P-value of Mann-Whitney $\mathrm{U}$ test for continuous variables (significant $\mathrm{P}$-value $<0.05$ )

2 -aminosalycites, immune suppressors, steroids

${ }^{3}$ counted independently 
and $59.6 \%$ women. The median age of patients was 31 years of age (IQR 29-32 years).

The basic characteristics of all the groups (operated CD patients, non-operated CD patients and the healthy cohort) are included in Table 1.

Among the most commonly performed surgeries in this study was the ileocecal resection, performed in 88 of the cases. The right hemicolectomy was performed 14 times. Both the resection of stenotic anastomosis and the left hemicolectomy were performed 15 times each. The surgery was performed laparoscopically in 35 of the cases, open surgery was performed 97 times.

Side-to-side anastomosis $(n=97)$ prevailed over endto-end anastomosis $(n=24)$. Terminal ileostomy with subtotal colectomy was performed in 11 patients.

\section{Results}

When comparing preoperative and postoperative QoL in the operated group, we registered an improvement of the overall QoL. Postoperative improvement of QoL was detected in 104 of the operated patients (78.8 \%), 2 patients

\section{Figure. Distribution of overall QoL score}

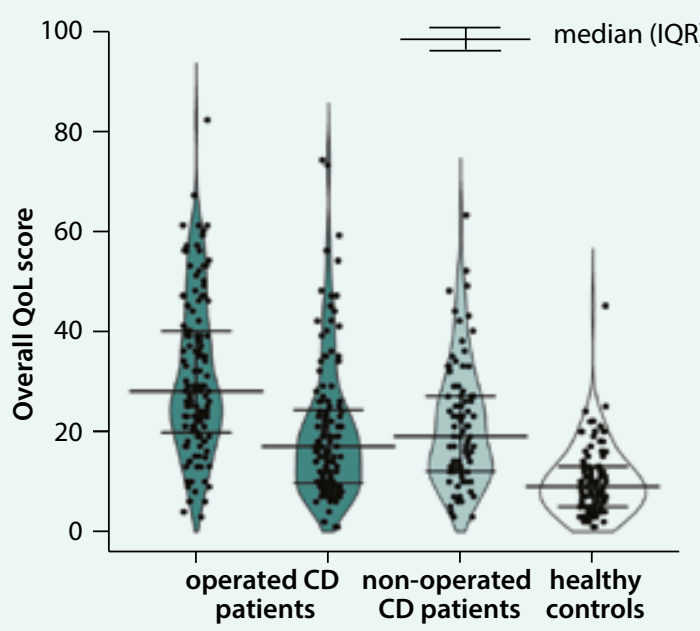

preoperative postoperative

\section{Table 2. Preoperative and postoperative QoL in operated CD patients}

\begin{tabular}{|c|c|c|c|c|c|c|}
\hline QoL scales $(\mathrm{N}=132)$ & $\begin{array}{c}\text { preoperative QoL } \\
\text { mean }( \pm S D)\end{array}$ & $\begin{array}{c}\text { postoperative QoL } \\
\text { mean ( } \pm \text { SD) }\end{array}$ & $\mathbf{P}^{1}$ & $\begin{array}{c}+ \\
\mathrm{N}(\text { row \%) }\end{array}$ & $\begin{array}{l}\text { no change } \\
\text { N (row \%) }\end{array}$ & N (row \%) \\
\hline abdomen pain and discomfort & $37.9( \pm 24.0)$ & $14.4( \pm 17.0)$ & $<0.001$ & 107 (81.1\%) & $16(12.1 \%)$ & $9(6.8 \%)$ \\
\hline questions about stool & $24.3( \pm 23.2)$ & $15.7( \pm 16.6)$ & $<0.001$ & 75 (56.8 \%) & $21(15.9 \%)$ & $36(27.3 \%)$ \\
\hline urinary functions & $6.0( \pm 12.6)$ & $4.5( \pm 9.3)$ & 0.152 & $24(18.2 \%)$ & $88(66.7 \%)$ & $20(15.2 \%)$ \\
\hline $\begin{array}{l}\text { physical functioning and body } \\
\text { image }\end{array}$ & $48.7( \pm 28.7)$ & $36.3( \pm 25.9)$ & $<0.001$ & $75(56.8 \%)$ & $16(12.1 \%)$ & $41(31.1 \%)$ \\
\hline sexual functions & $41.2( \pm 26.1)$ & $27.7( \pm 20.5)$ & $<0.001$ & 69 (52.7\%) & $46(35.1 \%)$ & $16(12.2 \%)$ \\
\hline quality of defecation & $31.5( \pm 22.3)$ & $20.9( \pm 20.8)$ & $<0.001$ & $88(66.7 \%)$ & 26 (19.7\%) & $18(13.6 \%)$ \\
\hline overall QoL & $30.7( \pm 15.5)$ & $19.9( \pm 13.8)$ & $<0.001$ & $104(78.8 \%)$ & $2(1.5 \%)$ & $26(19.7 \%)$ \\
\hline
\end{tabular}

${ }^{1}$ P-value of Wilcoxon signed-rank test (Bonferroni correction; significant P-value $<0.007$ )

\section{Table 3. Comparison of QoL of patients before and after surgery for CD with QoL of non-operated CD patients} and healthy controls

QoL scales

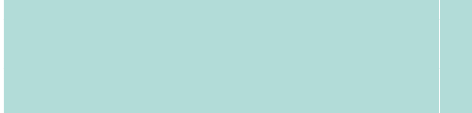

abdomen pain and discomfort

questions about stool

urinary functions

physical functioning and body image

sexual functions

quality of defecation

overall QoL operated CD patients

$(\mathrm{N}=132)$ non-operated $\mathrm{CD}$ patients

$(\mathrm{N}=83)$

\begin{tabular}{c|c}
$\begin{array}{c}\text { preoperative } \\
\text { mean }( \pm \text { SD) }\end{array}$ & $\begin{array}{r}\text { postoperative } \\
\text { mean }( \pm \text { SD })\end{array}$ \\
\hline $37.9( \pm 24.0)^{\mathrm{ab}}$ & $14.4( \pm 17.0)^{\mathrm{b}}$ \\
\hline $24.3( \pm 23.2)^{\mathrm{ab}}$ & $15.7( \pm 16.6)^{\mathrm{ab}}$ \\
$6.0( \pm 12.6)$ & $4.5( \pm 9.3)^{\mathrm{a}}$ \\
$48.7( \pm 28.7)^{\mathrm{b}}$ & $36.3( \pm 25.9)^{\mathrm{b}}$ \\
$41.2( \pm 26.1)^{\mathrm{b}}$ & $27.7( \pm 20.5)^{\mathrm{b}}$ \\
$31.5( \pm 22.3)^{\mathrm{ab}}$ & $20.9( \pm 20.8)^{\mathrm{b}}$ \\
$30.7( \pm 15.5)^{\mathrm{ab}}$ & $19.9( \pm 13.8)^{\mathrm{b}}$ \\
\end{tabular}

mean ( $\pm \mathrm{SD}$ )

$17.9( \pm 14.3)^{\mathrm{b}}$

$9.3( \pm 11.5)^{\mathrm{b}}$

$7.9( \pm 10.4)^{\mathrm{b}}$

$39.9( \pm 23.0)^{\mathrm{b}}$

$31.4( \pm 24.5)^{b}$

$21.8( \pm 18.1)^{\mathrm{b}}$

$21.3( \pm 12.3)^{\mathrm{b}}$ controls $(\mathrm{N}=104)$

a significant difference from the group 'non-operated CD patients',

${ }^{b}$ significant difference from the group 'controls' (P-value of Mann-Whitney U test with Bonferroni correction; significant $\mathrm{P}$-value $\left.<0.001\right)$. 


\section{Table 4. Analysis of factors affecting overall postoperative QoL}

\begin{tabular}{|c|c|c|c|c|}
\hline \multirow{2}{*}{$\begin{array}{l}\text { factors } \\
(\mathrm{N}=132)\end{array}$} & & \multicolumn{2}{|c|}{ overall postoperative QoL } & \multirow[t]{2}{*}{$\mathbf{P}^{1}$} \\
\hline & & $\mathbf{N}$ & mean $( \pm S D)$ & \\
\hline \multirow{2}{*}{ sex } & male & 59 & $15.5( \pm 10.1)$ & \multirow{2}{*}{$<0.001$} \\
\hline & female & 73 & $23.5( \pm 15.4)$ & \\
\hline \multirow{2}{*}{ age at diagnosis } & $\leq 40$ & 118 & $20.3( \pm 14.2)$ & \multirow{2}{*}{0.369} \\
\hline & $>40$ & 14 & $16.9( \pm 10.8)$ & \\
\hline \multirow{2}{*}{ age at surgery } & $\leq 40$ & 103 & $20.2( \pm 13.6)$ & \multirow{2}{*}{0.408} \\
\hline & $>40$ & 29 & $19.0( \pm 14.8)$ & \\
\hline \multirow{3}{*}{ cigarette smoking } & Smoker & 45 & $21.7( \pm 16.5)$ & \multirow{3}{*}{0.280} \\
\hline & Ex-smoker & 31 & $20.8( \pm 11.3)$ & \\
\hline & Non-smoker & 56 & $18.0( \pm 12.8)$ & \\
\hline \multirow{5}{*}{ location of disease } & L1 - ileum & 71 & $21.0( \pm 14.0)$ & \multirow{3}{*}{0.180} \\
\hline & L2 - colon & 9 & $23.6( \pm 14.0)$ & \\
\hline & L3 - ileum + colon & 52 & $17.9( \pm 13.6)$ & \\
\hline & not L4 & 126 & $19.5( \pm 13.2)$ & \\
\hline & L4 - upper GIT (concomitant) & 6 & $28.8( \pm 24.0)$ & דדר. \\
\hline \multirow{3}{*}{ behaviour of disease } & B1 - inflammatory & 19 & $22.9( \pm 14.0)$ & \multirow{3}{*}{0.339} \\
\hline & B2 - stricturing & 73 & $18.6( \pm 13.0)$ & \\
\hline & B3 - penetrating & 40 & $20.8( \pm 15.2)$ & \\
\hline \multirow{2}{*}{ perianal disease } & no & 97 & $20.2( \pm 12.7)$ & \multirow{2}{*}{0.071} \\
\hline & yes & 35 & $19.0( \pm 16.8)$ & \\
\hline \multirow{4}{*}{ surgical procedure } & IC resection & 88 & $19.8( \pm 13.4)$ & \multirow{4}{*}{0.720} \\
\hline & right side hemicolectomy & 14 & $17.6( \pm 13.0)$ & \\
\hline & resection of anastomosis & 15 & $17.9( \pm 10.8)$ & \\
\hline & resection of left colon or rectum & 15 & $24.7( \pm 19.3)$ & \\
\hline \multirow{3}{*}{ anastomosis } & $\mathrm{S}-\mathrm{t}-\mathrm{S}^{*}$ & 97 & $19.2( \pm 13.2)$ & \multirow{3}{*}{0.479} \\
\hline & $\mathrm{E}-\mathrm{t}-\mathrm{E}^{* *}$ & 24 & $20.8( \pm 13.6)$ & \\
\hline & terminal ileostomy & 11 & $24.6( \pm 19.7)$ & \\
\hline \multirow{2}{*}{ surgical approach } & open & 97 & $19.0( \pm 13.0)$ & \multirow{2}{*}{0.194} \\
\hline & laparoscopic & 35 & $22.5( \pm 15.8)$ & \\
\hline \multirow{2}{*}{ complications } & no & 88 & $18.9( \pm 12.8)$ & \multirow{2}{*}{0.344} \\
\hline & yes & 44 & $22.0( \pm 15.6)$ & \\
\hline & $<5$ years & 61 & $20.7( \pm 13.3)$ & \\
\hline $\begin{array}{l}\text { time from diagnosis to surgery } \\
\text { (years) }\end{array}$ & $5-9$ years & 31 & $17.4( \pm 11.3)$ & 0.651 \\
\hline & $\geq 10$ years & 40 & $20.6( \pm 16.3)$ & \\
\hline & 0 & 75 & $20.7( \pm 15.3)$ & \\
\hline former operations & 1 & 31 & $19.3( \pm 12.2)$ & 0.934 \\
\hline & $\geq 2$ & 26 & $18.5( \pm 11.3)$ & \\
\hline idities & no & 91 & $20.1( \pm 14.5)$ & 0772 \\
\hline comorninities & at least one & 41 & $19.4( \pm 12.5)$ & 0.112 \\
\hline & no medication & 17 & $19.6( \pm 13.9)$ & \\
\hline enerative medicatic & biological treatment & 10 & $21.3( \pm 11.6)$ & 0897 \\
\hline preoperative meuicatiol & 1 type of medication ${ }^{2}$ & 36 & $20.1( \pm 14.3)$ & 0.891 \\
\hline & $2-3$ types of medication ${ }^{2}$ & 69 & $19.7( \pm 14.2)$ & \\
\hline
\end{tabular}

1 P-value of Mann-Whitney $U$ test or Kruskal-Wallis test (significant P-value $<0.05$ );

2 5-aminosalycites, immune suppressors, steroids.

"S-t-S - side-to-side

${ }^{* *} E-t-E$ - end-to-end 
did not register any changes in their QoL (1.5\%) and the QoL decreased in 26 patients (19.7\%). A statistically relevant improvement of postoperative QoL was found in most of the observed factors - abdominal pain and discomfort, stool (frequency and content), physical condition and body image, sexual functions and quality of defecation. The only factor for which no statistically relevant difference was found were urinary functions. The comparison of preoperative and postoperative QoL is shown in Table 2.

Furthermore, the overall QoL of all 3 groups (operated $C D$ patients, non-operated $C D$ patients and the healthy cohort) was compared. The lowest value of QoL was recorded in CD patients before surgery. In the postoperative period, the operated CD patients had a QoL comparable to the CD patients without the need of surgery, who supposedly had a less aggressive form of CD. The healthy group clearly had the best QoL. The results were statistically significant. The comparison of the QoL of all three groups can be seen in Table 3.

A graphical representation and distribution of QoL of all three observed groups is shown in Fig.

A careful analysis of the individual factors affecting postoperative QoL was subsequently performed. All the factors included in the analysis are listed in Table 4. The only statistically significant factor affecting overall QoL was gender. A comparison of the individual components according to gender as a factor affecting postoperative QoL can be seen in Table 5. A statistically significant difference was found in the comparison of individual components, namely abdominal pain and discomfort, physical condition and body image and sexual functions.

\section{Discussion}

Despite recently introduced new modalities of conservative treatment, including biological treatment; the results show that this has not led to a significant decrease in the number of surgical performances in $C D$ patients and surgical treatment still plays an important and crucial role in CD therapy [22-24].

Our group of $C D$ patients who had undergone surgery manifested a statistically significant improvement of QoL in the period of two months after the surgery. Except urinary functions, QoL improved in all the monitored factors. In 2003, Delaney et al [25] published their study of a group of 142 operated CD patients focused on postoperative QoL 30 days after surgery. They came to a similar conclusion that a surgically induced remission improved CD patients' QoL measured shortly after surgery. Other studies and review articles also showed postoperative QoL improvement [26-28]. Nevertheless, the duration and level of this QoL remains uncertain in the long term, as clinical postoperative recurrence of the disease is $55-65 \%$ within 5 years $[13,14,16,29]$.

When comparing all 3 studied groups (operated CD patients, non-operated CD patients and a healthy cohort), the healthy cohort had, as we originally expected, the highest QoL, as well as the best values in each particular scale (abdominal pain and discomfort, questions related to stool, urinary functions, physical condition, body image, sexual functions and quality of defecation).

The second control group consisted of CD patients who had not undergone surgical treatment during their life. We presupposed a less complicated and less aggressive progression of the disease in this group than in the operated one. When comparing this group and the group of CD patients in the preoperative period, the non-operated group had significantly higher overall QoL. A subsequent comparison of QoL of the CD patients in their postoperative period showed comparable results to the non-operated group.

In our group of operated patients, $19.7 \%(n=26)$ experienced a negative change in their overall QoL. This group of patients reported a decrease in all the assessed scales (except urinary functions), most of all regarding stool, physical condition and body image. We tried to focus on this group and determine the possible factors or cause of the negative perception of their postoperative state. Unfortunately, not even an extensive analysis of the individual factors showed any statistically significant results. Only the penetrating and inflammatory form of the disease along with an interval of 5-9 years between being diagnosed with $C D$ and surgical treatment suggested a possible prediction of

Tab. 5. Comparison of postoperative QoL between men and women

\begin{tabular}{|c|c|c|c|}
\hline postoperative QoL scales & $\begin{array}{l}\text { men }(N=59) \\
\text { mean }( \pm S D)\end{array}$ & $\begin{array}{c}\text { women }(N=73) \\
\text { mean }( \pm S D)\end{array}$ & $\mathbf{P}$ \\
\hline abdomen pain and discomfort & $10.3( \pm 10.6)$ & $17.7( \pm 20.3)$ & $<0.001$ \\
\hline questions about stool & $13.6( \pm 12.0)$ & $17.5( \pm 19.5)$ & 0.118 \\
\hline urinary functions & $3.3( \pm 6.6)$ & $5.4( \pm 10.9)$ & 0.067 \\
\hline physical functioning and body image & $29.5( \pm 21.9)$ & $41.8( \pm 27.7)$ & $<0.001$ \\
\hline sexual functions & $20.2( \pm 17.5)$ & $33.8( \pm 20.8)$ & $<0.001$ \\
\hline quality of defecation & $15.8( \pm 15.1)$ & $25.0( \pm 23.8)$ & 0.113 \\
\hline overall QoL & $15.5( \pm 10.1)$ & $23.5( \pm 15.4)$ & $<0.001$ \\
\hline
\end{tabular}

P-value of Mann-Whitney U test (Bonferroni correction; significant P-value $<0.007$ ) 
negative postoperative QoL, however, it did not reach statistical relevance.

In our analysis of the individual factors affecting postoperative QoL, we found only one statistically significant factor which was gender. Male gender was found to be a predictor of an improvement of QoL after surgery. Tabibian et al [30] obtained similar results in their study. Their cohort consisted of 136 patients with IBD who completed a standardized QoL questionnaire, out of which 78 were CD patients. Tabibian, apart from a stronger perception of stress and more frequent relapse of $C D$, determined female gender as a general risk factor for lower QoL in CD patients. His results reached statistical significance.

Similarly, Stjernman et al [31] in their study of a large group of $447 \mathrm{CD}$ patients demonstrated that female gender is one of the factors related to lower QoL in CD patients. As reasons for decreased QoL in women, they stated problems and dissatisfaction with body image and concerns related to an influence of the disease on their sexual life. In our subanalysis of the group of female patients (Table 5), we reached identical results, which were also statistically significant.

In 2000, Casellas et al [11] in their study determined gender as the only statistically significant factor among the basic characteristics of CD patients. Although a difference was recorded in the area of bowel symptoms and abdominal discomfort, other areas (emotional, physical and sexual) showed no difference between genders.

Furthermore, the same results were obtained in recently published studies. Magalhaes et al [32] in 2014 in his group of 150 IBD patients (92 CD patients) noted a significant decrease in QoL related to female gender. Female gender also seems to be an important factor for lower QoL in ulcerative colitis. In a Chinese cohort with 224 ulcerative colitis patients, the female patients had a decreased QoL score than male patients [33].

Some results of our analysis suggested possible predictive values of postoperative QoL, but did not reach statistical significance. For instance, cigarette smokers $(p=0,280)$ or patients with a location of the disease in the colon $L 2(p=0,180)$ inclined towards a lowered QoL, the results were, however, not statistically significant. Furthermore, another frequently mentioned factor of a decrease in the postoperative QoL is an occurrence of postoperative complications. Delaney et al [25] described a connection between worsened postoperative QoL and a higher occurrence of postoperative complications recorded in a 30-day interval after surgery. According to our results, a higher occurrence of postoperative complications was also related to a lower QoL, however, the difference was not statistically significant.

The advantages of the laparoscopic technique as opposed to open surgery are widely recognized today. They include a shorter length of hospitalization, an earlier resumption of peristalsis, lower postoperative morbidity, a lower tendency of postoperative adhesion or incisional hernia and a better cosmetic effect [34]. A pos- itive influence of laparoscopy in comparison to open surgery on postoperative QoL of CD patients, however, was surprisingly not demonstrated $[19,35,36]$. These studies correlate with our results. When comparing approach of surgical treatment, no statistically significant difference in postoperative QoL was found.

\section{Conclusion}

In our cohort, the CD patients had significantly improved QoL in the postoperative period. After that, the QoL was comparable to the group of patients with CD who did not need to undergo a surgery for CD. The best QoL was perceived by the healthy cohort. The only significant factor affecting overall QoL was gender (male gender was evaluated as a predictor of postoperative QoL improvement).

\section{Ethical standard statement}

All procedures which followed were in accordance with the ethical standards of the responsible committee on human experimentation (institutional and national) and with the Helsinki Declaration of 1975, as revised in 2008.

\section{References}

1. Burisch J, Weimers $P$, Pedersen $N$ et al. Health-related quality of life improves during one year of medical and surgical treatment in a European population-based inception cohort of patients with Inflammatory Bowel Disease - An ECCO-EpiCom study. J Crohns Colitis 2014; 8(9): 1030-1042. Dostupné z DOI: <http://dx.doi.org/10.1016/j. crohns.2014.01.028>

2. Moradkhani A, Beckman LJ, Tabibian JH. Health-related quality of life in inflammatory bowel disease: Psychosocial, clinical, socioeconomic, and demographic predictors. J Crohns Colitis 2013; 7(6): 467473. Dostupné z DOI: <http://dx.doi.org/10.1016/j.crohns.2012.07.012>.

3. Umanskiy $\mathrm{K}$, Fichera A. Health related quality of life in inflammatory bowel disease: The impact of surgical therapy. World J Gastroenterol 2010; 16(40): 5024-5034.

4. Kunovsky L, Hemmelova B, Kala Z et al. Crohn disease and pregnancy: a case report of an acute abdomen. Int J Colorectal Dis 2016; 31(8): 1493-1494. Dostupné z DOI: <http://dx.doi.org/10.1007/ s00384-016-2554-1>.

5. Mikocka-Walus AA, Turnbull DA, Andrews JM et al. Psychological problems in gastroenterology outpatients: A South Australian experience. Psychological co-morbidity in IBD, IBS and hepatitis C. Clin Pract Epidemiol Ment Health 2008; 4: 15. Dostupné z DOI: <http://dx.doi. org/10.1186/1745-0179-4-15>.

6. Gavrilescu O, Mihai C, Anton-Paduraru DT et al. Impact of Inflammatory Bowel Diseases on Quality of Life. Revista de Cercetare si Interventie Sociala 2015; 50: 80-95.

7. Herrera-deGuise C, Casellas F, Robles V et al. Predictive value of early restoration of quality of life in Crohn's disease patients receiving antitumor necrosis factor agents. J Gastroenterol Hepatol 2015; 30(2): 286-291. Dostupné z DOI: <http://dx.doi.org/10.1111/jgh.12803>.

8. Riss S, Schwameis $K$, Mittlböck $M$ et al. Sexual function and quality of life after surgical treatment for anal fistulas in Crohn's disease. Tech Coloproctol 2013; 17(1): 89-94. Dostupné z DOI: <http://dx.doi. org/10.1007/s10151-012-0890-x>.

9. Iglesias-Rey M, Barreiro-de Acosta M, Caamaño-isorna $F$ et al. Psychological Factors Are Associated with Changes in the Health-related Quality of Life in Inflammatory Bowel Disease. Inflamm Bowel Dis 2014; 20(1): 92-102. Dostupné z DOI: <http://dx.doi.org/10.1097/01. MIB.0000436955.78220.bc>.

10. Lix L, Graff L, Walker J et al. Longitudinal Study of Quality of Life and Psychological Functioning for Active, Fluctuating, and Inactive 
Disease Patterns in Inflammatory Bowel Disease. Inflamm Bowel Dis 2008; 14(11): 1575-1584. Dostupné z DOI: <http://dx.doi.org/10.1002/ ibd.20511>.

11. Casellas F, López-Vivancos J, Badia X et al. Impact of surgery for Crohn's disease on health-related quality of life. Am J Gastroenterol 2000; 95(1): 177-182. Dostupné z DOI: <http://dx.doi.org/10.111 1/j.1572-0241.2000.01681.x>.

12. Cohen RD. The quality of life in patients with Crohn's disease. Aliment Pharmacol Ther 2002; 16(9): 1603-1609.

13. Aratari A, Papi C, Leandro $G$ et al. Early versus late surgery for ileo-caecal Crohn's disease. Aliment Pharmacol Ther 2007; 26(10): 1303-1312. Dostupné z DOI: <http://dx.doi.org/10.111 1/j.1365-2036.2007.03515.x>.

14. De Cruz P, Kamm MA, Hamilton AL et al. Crohn's disease management after intestinal resection: a randomised trial. Lancet 2015; 385(9976): 1406-1417. Dostupné z DOI: <http://dx.doi.org/10.1016/ S0140-6736(14)61908-5>

15. Bernell O, Lapidus A, Hellers G. Risk factors for surgery and postoperative recurrence in Crohn's disease. Ann Surg 2000; 231(1): 38-45.

16. Bobanga I, Bai S, Swanson M et al. Factors influencing disease recurrence after ileocolic resection in adult and pediatric onset Crohn's disease. Am J Surg 2014; 208(4): 591-596. Dostupné z DOI: <http:// dx.doi.org/10.1016/j.amjsurg.2014.06.008>.

17. Fornaro $R$, Caratto $E_{\text {, Caratto }} M$ et al. Post-operative recurrence in Crohn's disease. Critical analysis of potential risk factors. An update. Surgeon 2015; 13(6): 330-347. Dostupné z DOI: <http://dx.doi. org/10.1016/j.surge.2015.04.002>

18. Kala Z, Marek F, Válek V et al. Crohn's disease surgery. Vnitř Lék 2014; 60(7-8): 617-623.

19. Kunovsky L, Kala Z, Mitas L et al. Quality of life after bowel resection for Crohn's disease - first results. Rozhl Chir 2016; 95(12): 444-448.

20. Whistance RN, Conroy T, Chie W et al. Clinical and psychometric validation of the EORTC QLQ-CR29 questionnaire module to assess health-related quality of life in patients with colorectal cancer. Eur J Cancer 2009; 45(17): 3017-3026. Dostupné z DOI: <http://dx.doi. org/10.1016/j.ejca.2009.08.014>.

21. Gujral S, Conroy T, Fleissner $C$ et al. Assessing quality of life in patients with colorectal cancer: An update of the EORTC quality of life questionnaire. Eur J Cancer 2007; 43(10): 1564-1573. Dostupné z DOI: <http://dx.doi.org/10.1016/j.ejca.2007.04.005>.

22. Bewtra M, Su C, Lewis JD. Trends in Hospitalization Rates for Inflammatory Bowel Disease in the United States. Clin Gastroenterol Hepatol 2007; 5(5): 597-601. Dostupné z DOI: <http://dx.doi.org/10.1016/j. cgh.2007.01.015>.

23. de Buck van Overstraeten A, Wolthuis A, D'Hoore A. Surgery for Crohn's disease in the era of biologicals: A reduced need or delayed verdict? World J Gastroenterol 2012; 18(29): 3828-3832. Dostupné z DOI: <http://dx.doi.org/10.3748/wjg.v18.i29.3828>.

24. Ferrari L, Krane MK, Fichera A. Inflammatory bowel disease surgery in the biologic era. World J Gastrointest Surg 2016; 8(5): 363-370. Dostupné z DOI: <http://dx.doi.org/10.4240/wjgs.v8.i5.363>.

25. Delaney $C P$, Kiran RP, Senagore AJ et al. Quality of life improves within 30 days of surgery for Crohn's disease. J Am Coll Surg 2003; 196(5): 714-721. Dostupné z DOI: <http://dx.doi.org/10.1016/ S1072-7515(03)00131-5>.
26. Yazdanpanah Y, Klein O, Gambiez L et al. Impact of surgery on quality of life in Crohn's disease. Am J Gastroenterol 1997; 92(10): 1897-1900.

27. Thirlby RC, Land JC, Fenster LF et al. Effect of Surgery on Health-Related Quality of Life in Patients With Inflammatory Bowel Disease: A Prospective Study. Arch Surg 1998; 133(8): 826-832.

28. Bączyk G, Formanowicz D, Gmerek $Ł$ et al. Health-related quality of life assessment among patients with inflammatory bowel diseases after surgery - review. Gastroenterology Rev 2017; 12(1): 6-16. Dostupné z DOI: <http://dx.doi.org/10.5114/pg.2016.64037>.

29. Achkar JP, Hanauer SB. Medical therapy to reduce postoperative Crohn's disease recurrence. Am J Gastroenterol 2000; 95(5): 1139-1146. Dostupné z DOI: <http://dx.doi.org/10.1111/j.1572-0241.2000.02000. $x>$.

30. Tabibian A, Tabibian JH, Beckman LJ et al. Predictors of health-related quality of life and adherence in Crohn's disease and ulcerative colitis: implications for clinical management. Dig Dis Sci 2015; 60(5): 1366-1374. Dostupné z DOI: <http://dx.doi.org/10.1007/ s10620-014-3471-1>

31. Stjernman $\mathrm{H}$, Tysk $\mathrm{C}$, Almer $\mathrm{S}$ et al. Worries and concerns in a large unselected cohort of patients with Crohn's disease. Scand J Gas troenterol 2010; 45(6): 696-706. Dostupné z DOI: <http://dx.doi. org/10.3109/00365521003734141>.

32. Magalhães J, Castro FD de, Carvalho PB et al. Quality of life in patients with inflammatory bowel disease: importance of clinical, demographic and psychosocial factors. Arq Gastroenterol 2014; 51(3): 192-197.

33. Zheng K, Zhang S, Wang C et al. Health-Related Quality of Life in Chinese Patients with Mild and Moderately Active Ulcerative Colitis. PLoS ONE 2015; 10(4): e0124211. Dostupné z DOI: <http://dx.doi. org/10.1371/journal.pone.0124211>.

34. Kunovský L, Marek F, Kala Z et al. Possibilities of minimally invasive surgery in patients with Crohn's disease and ulcerative colitis. Gastroenterol Hepatol 2017; 71(1): 29-35.

35. Thaler K, Dinnewitzer A, Oberwalder M et al. Assessment of longterm quality of life after laparoscopic and open surgery for Crohn's disease. Colorectal Dis 2005; 7(4): 375-381. Dostupné z DOI: <http:// dx.doi.org/10.1111/j.1463-1318.2005.00769.x>.

36. Scarpa M, Ruffolo C, Bassi D et al. Intestinal surgery for Crohn's disease: Predictors of recovery, quality of life, and costs. J Gastrointest Surg 2009; 13(12): 2128-2135. Dostupné z DOI: <http://dx.doi. org/10.1007/s11605-009-1044-y>.

\section{Lumir Kunovsky, M.D. $\square$ kunovsky.lumir@fnbrno.cz}

Department of Surgery, University Hospital

Medicine of adult age (Bohunice), and Faculty of Medicine,

Masaryk University, Brno, Czech Republic

www.fnbrno.cz

www.med.muni.cz

Doručeno do redakce 15. 10. 2017

Prijato po recenzi 12. 1. 2018 